\title{
The Development of a Qualitative Real-Time RT-PCR Assay for the Detection of Hepatitis C Virus
}

\author{
Celine Herra \\ Technological University Dublin, celine.herra@tudublin.ie
}

A. Clancy

Department of Clinical Microbiology, St. James's Hospital, Dublin 8, Ireland

B. Crowley

Department of Clinical Microbiology, St. James's Hospital, Dublin 8, Ireland

See next page for additional authors

Follow this and additional works at: https://arrow.tudublin.ie/scschbioart

Part of the Medicine and Health Sciences Commons

\section{Recommended Citation}

Herra, C. (2008) The development of a qualitative real-time RT-PCR assay for the detection of hepatitis C virus. Eur J Clin Microbiol Infect Dis (2008) 27:1177-1182, doi:10.1007/s10096-008-0556-9

This Article is brought to you for free and open access by the School of Biological Sciences at ARROW@TU Dublin. It has been accepted for inclusion in Articles by an authorized administrator of ARROW@TU Dublin. For more information, please contact arrow.admin@tudublin.ie, aisling.coyne@tudublin.ie,gerard.connolly@tudublin.ie.

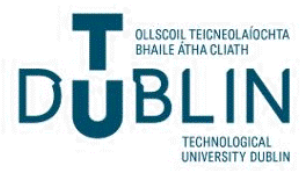




\section{Authors}

Celine Herra, A. Clancy, B. Crowley, and H. Niesters 


\title{
The development of a qualitative real-time RT-PCR assay for the detection of hepatitis $C$ virus
}

\author{
A. Clancy $\cdot$ B. Crowley $\cdot$ H. Niesters $\cdot$ C. Herra
}

Received: 19 February 2008 / Accepted: 12 May 2008 / Published online: 13 June 2008

(C) Springer-Verlag 2008

\begin{abstract}
Real-time polymerase chain reaction (PCR) represents a favourable option for the detection of hepatitis $\mathrm{C}$ virus (HCV). A real-time reverse transcriptase PCR (RTPCR) assay was developed as a qualitative diagnostic screening method for the detection of HCV using the ABI PRISM $^{\circledR} 7500$ Sequence Detection System. The primers and probe were designed to target the $5^{\prime}$-untranslated region of the hepatitis $\mathrm{C}$ viral genome. A second heterologous probe assay was developed for the detection of the haemagglutinin gene of phocine distemper virus (PDV) and was used as an internal control. A semi-automated $\mathrm{HCV}$ extraction method was also implemented using the ABI PRISM ${ }^{\mathrm{TM}} 6100$ Nucleic Acid PrepStation. The HCV assay was optimised as a qualitative singleplex RT-PCR assay with parallel testing of the target and internal control. The assay results $(n=200)$ were compared to the COBAS AMPLICOR $^{\mathrm{TM}} \mathrm{HCV}$ Test v2.0 assay. The assay demonstrated a high rate of sensitivity (99\%), specificity $(100 \%)$ and an acceptable limit of detection (LOD) of $100 \mathrm{IU} / \mathrm{ml}$. The development of a qualitative multiplex assay for the simultaneous detection of $\mathrm{HCV}$ and internal control
\end{abstract}

A. Clancy $(\bowtie) \cdot$ B. Crowley

Department of Clinical Microbiology, St. James's Hospital, Dublin 8, Ireland

e-mail: aclancy@stjames.ie

\section{H. Niesters}

Department of Medical Microbiology, Section Virology, UMCG, University Medical Center Groningen,

De Brug, Hanzeplein 1, P.O. Box 30.001, 9700 RB Groningen,

The Netherlands

C. Herra

School of Biological Sciences, Dublin Institute of Technology,

Kevin Street,

Dublin 8, Ireland indicates the same high rates of sensitivity and specificity. This sensitive real-time assay may prove to be a valuable method for the detection of $\mathrm{HCV}$.

\section{Introduction}

Hepatitis $\mathrm{C}$ virus (HCV) is responsible for most cases of blood-borne hepatitis and is the leading cause of chronic liver disease worldwide, with a global prevalence of hepatitis $\mathrm{C}$ infection of approximately $2 \%$ [1]. Traditional laboratory assays for the diagnosis and management of $\mathrm{HCV}$ infection include serological tests to detect and classify antibody response and to determine the $\mathrm{HCV}$ RNA genotype. Many limitations are, however, associated with the serological diagnosis of hepatitis C. These limitations include a requirement for confirmation by other assays (e.g. immunoblots), reduced specificity in low-risk populations, reduced sensitivity in cases of early infection and immunosuppression, and, most importantly, the inability to distinguish between resolved and chronic infection [2,3]. Reverse transcriptase polymerase chain reaction (RT-PCR) is considered to be the "gold standard" for the detection of viral genomic RNA in serum or plasma. The detection of RNA exclusively demonstrates active viral infection [3]. Therefore, unlike serology, HCV RNA testing can be used for the diagnosis of acute hepatitis before seroconversion, in seronegative patients with immune deficiency and for investigating congenital $\mathrm{HCV}$ infection. HCV RNA detection is also useful for confirming indeterminate serological results and for monitoring response to treatment $[3,4]$.

In the last ten years, many commercial nucleic acid amplification assays for qualitative and quantitative $\mathrm{HCV}$ detection have become available. However, these methods 
can be laborious and time-consuming. Automated technologies such as real-time PCR represent a more favourable option for accurate qualitative and quantitative hepatitis $\mathrm{C}$ detection. Unlike conventional, end-point PCR, where amplicon amplification and detection involve separate steps and run the risk of cross-contamination between samples and/or PCR product and where sensitivity is often limited by the resolution of the detection method (e.g. agarose gel electrophoresis), real-time PCR systems offer rapid combined amplification and realtime, probe-based detection of amplicons in a closed automated system. However, whilst the commercial real-time PCR assays are appealing, the cost may prohibit their introduction into routine diagnostic laboratories. Nevertheless, many open-channel real-time PCR platforms are now available. These flexible systems function as analytical platforms that allow full customisation of the diagnostic assay design.

Despite the advantages offered by real-time detection platforms, sample preparation remains the major ratelimiting step. Conventional manual nucleic acid extraction methods are time-consuming, labour-intensive and susceptible to contamination. Fully automated sample preparation systems are increasingly available to accompany real-time platforms. These systems offer the rapid isolation of nucleic acids on a high-throughput scale. Such systems are, however, costly. Semi-automated nucleic acid preparation systems, such as the ABI PRISM ${ }^{\mathrm{TM}} 6100$ Nucleic Acid PrepStation (Applied Biosystems, Foster City, CA), could provide a more cost-effective alternative. This system is a small, bench-top instrument comprised of a programmable vacuum manifold and a 96-well filtration plate, which uses solid-phase extraction chemistry for the purification of DNA or RNA from a range of sample types. Development of a combined ABI $6100 \mathrm{HCV}$ extraction method with a real-time ABI 7500 RT-HCV PCR assay may, therefore, facilitate the rapid and accurate detection of $\mathrm{HCV}$.

\section{Materials and methods}

A total of 650 serum samples were used for the development and optimisation of the RT-PCR assay. A further 200 samples were used in a clinical trial. All samples were collected from randomly selected patients attending the hepatology clinic at St. James's Hospital, Dublin, Ireland. Samples were separated and frozen at $-20^{\circ} \mathrm{C}$ within $4 \mathrm{~h}$ of collection. A $200-\mu l$ aliquot of serum was removed and tested for HCV-RNA by the COBAS AMPLICOR ${ }^{\mathrm{TM}} \mathrm{HCV}$ Test v2.0 assay (Roche Diagnostics GmbH, Mannheim, Germany). A 500- $\mu 1$ aliquot of serum was removed and tested using the ABI PRISM ${ }^{\circledR} 7500$ Sequence Detection System (Applied Biosystems, Foster City, CA).

A dilution series of the WHO Second International Standard 2003 for HCV RNA (National Institute for
Biological Standards and Control (NIBSC), code 96/798, Hertfordshire, UK) was used to determine the lower limit of detection (LOD) of the RT-PCR assay. The HCV RNA Genotype Panel for Nucleic Acid Amplification Techniques (NIBSC, code 02/202, Hertfordshire, UK) and the Quality Control for Molecular Diagnostics (QCMD) 2002 and 2004 HCV Proficiency Panels (QCMD, Glasgow, Scotland) were also used to assess assay performance.

Template RNA was extracted from $500 \mu$ of serum samples using the ABI PRISM ${ }^{\mathrm{TM}} 6100$ Nucleic Acid PrepStation (Applied Biosystems). A $70-\mu 1$ aliquot of master mix consisting of $100 \mu \mathrm{g}$ of proteinase K (Applied Biosystems), $25 \mu \mathrm{g}$ of polyadenylic acid (Sigma-Aldrich IRL Ltd., Dublin, Ireland) and $10 \mu \mathrm{l}$ of phocine distemper virus (PDV) internal control (IC) was added to the samples. The PDV IC was kindly supplied as a $1,000 \times$ stock cell culture by Dr. Hubert Niesters, Department of Virology, Erasmus MC, University Medical Center, Rotterdam, the Netherlands [5]. Samples were mixed and then incubated at room temperature for $1 \mathrm{~h}$. The lysates were applied to the ABI PRISMTM 6100 Nucleic Acid PrepStation and vacuum-based wash and elution steps were performed according to the manufacturer's instructions.

Prior to use, the ABI 6100 extraction protocol was evaluated by comparison with the QIAamp ${ }^{\circledR}$ UltraSens $^{\mathrm{TM}}$ virus extraction method (QIAGEN GmbH, Hilden, Germany). The manual extraction was performed according to the manufacturer's instructions using a 500- $\mu 1$ start volume. Forty serum samples were extracted by both methods.

All RNA eluates were converted to cDNA using the High-Capacity cDNA Archive Kit (Applied Biosystems). The cDNA conversion was performed according to the manufacturer's instructions with the following modifications. In the preparation step, the total reaction volume was optimised to $50 \mu \mathrm{l}$ and $\mathrm{RT}$ reaction conditions were optimised to $25^{\circ} \mathrm{C}$ for $10 \mathrm{~min}$, followed by $37^{\circ} \mathrm{C}$ for $1 \mathrm{~h}$.

$\mathrm{HCV}$-specific primers and probes were selected using Primer Express Software ${ }^{\mathrm{TM}}$ Version 2.0 (Applied Biosystems) (Table 1). The HCV-specific primer set, HCV-F (5'AGCGTCTAGCCATGGCGTT-3') and HCV-R (5'GCAAGCACCCTATCAGGCAGT-3') was designed to generate a 238-bp amplicon. The probe (5'-TCTGCGGA ACCGGTGAGT-MGB-3') was designed as a $5^{\prime}$-FAMlabelled minor groove binding (MGB) hybridisation probe. The PDV haemagglutinin gene (GenBank accession \#AF479274) was selected as the target for the PDV IC primer-probe set, details of which were supplied by Dr. Niesters (personal communication). The original primer set, PDV-F (5'-GGTGGGTGCCTTTTACAAGAAC-3') and PDV-R (5'-ATCTTCTTTCCTCAACCTCGTCC-3'), was modified to generate an 83-bp amplicon. The probe (5'ATGCAAGGGCCAATT-MGB-3') was re-designed as a 5'VIC-labelled MGB hybridisation probe (Table 2). 
Table 1 Multiple sequence alignment for hepatitis C virus (HCV)-specific primer-probe set for the 5'UTR of HCV genotypes

\begin{tabular}{|c|c|c|}
\hline $\begin{array}{l}\text { HCV forward primer (nucleotide position } \\
74-92^{\mathrm{a}} \text { ) }\end{array}$ & $\begin{array}{l}\text { HCV-MGB probe (nucleotide position } \\
147-164^{\mathrm{a}} \text { ) }\end{array}$ & $\begin{array}{l}\text { HCV reverse primer (nucleotide position } \\
288-308^{\mathrm{a}} \text { ) }\end{array}$ \\
\hline HCV1a AGCGTCTAGCCATGGCGTT & HCV1a TCTGCGGAACCGGTGAGT & HCV1a ACTGCCTGATAGGGTGCTTGC \\
\hline HCV1b AGCGTCTAGCCATGGCGTT & HCV1b TCTGCGGAACCGGTGAGT & HCV1b ACTGCCTGATAGGGTGCTTGC \\
\hline HCV1c AGCGTCTAGCCATGGCGTT & HCV1c TCTGCGGAACCGGTGAGT & HCV1c ACTGCCTGATAGGGTGCTTGC \\
\hline HCV2a AGCGTCTAGCCATGGCGTT & HCV2a TCTGCGGAACCGGTGAGT & HCV2a ACTGCCTGATAGGGTGCTTGC \\
\hline HCV2b AGCGTCTAGCCATGGCGTT & HCV2b TCTGCGGAACCGGTGAGT & HCV2b ACTGCCTGATAGGGTGCTTGC \\
\hline HCV2c AGCGTCTAGCCATGGCGTT & HCV2c TCTGCGGAACCGGTGAGT & HCV2c ACTGCCTGATAGGGTGCTTGC \\
\hline HCV3a AGCGCCTAGCCATGGCGTT & HCV3a TCTGCGGAACCGGTGAGT & HCV3a ACTGCCTGATAGGGTGCTTGC \\
\hline HCV3b AGCGTCTAGCCATGGCGTT & HCV3b TCTGCGGAACCGGTGAGT & HCV3b ACTGCCTGATAGGGTGCTTGC \\
\hline HCV4a AGCGTCTAGCCATGGCGTT & HCV4a TCTGCGGAACCGGTGAGT & HCV4a ACTGCCTGATAGGGTGCTTGC \\
\hline HCV4b AGCGTCTAGCCATGGCGTT & HCV4b TCTGCGGAACCGGTGAGT & HCV4b ACTGCCTGATAGGGTGCTTGC \\
\hline HCV4c AGCGTCTAGCCATGGCGTT & HCV4c TCTGCGGAACCGGTGAGT & HCV4c ACTGCCTGATAGGGTGCTTGC \\
\hline HCV4d AGCGTCTAGCCATGGCGTT & HCV4d TCTGCGGAACCGGTGAGT & HCV4d ACTGCCTGATAGGGTGCTTGC \\
\hline HCV4e AGCGTCTAGCCATGGCGTT & HCV4e TCTGCGGAACCGGTGAGT & HCV4e ACTGCCTGATAGGGTGCTTGC \\
\hline HCV4f AGCGTCTAGCCATGGCGTT & HCV4f TCTGCGGAACCGGTGAGT & HCV4f ACTGCCTGATAGGGTGCTTGC \\
\hline HCV5a AGCGTCTAGCCATGGCGTT & HCV5a TCTGCGGAACCGGTGAGT & HCV5a ACTGCCTGATAGGGTGCTTGC \\
\hline $\begin{array}{r}\text { HCV6a AGCGTCTAGCCATGGCGTT } \\
* * * * * * * * * * * * * * * * * *\end{array}$ & $\begin{array}{r}\text { HCV6a TCTGCGGAACCGGTGAGT } \\
* * * * * * * * * * * * * * * * * *\end{array}$ & $\begin{array}{r}\text { HCV6a ACTGCCTGATAGGGTGCTTGC } \\
* * * * * * * * * * * * * * * * * * * * *\end{array}$ \\
\hline Primer AGCGTCTAGCCATGGCGTT & Probe TCTGCGGAACCGGTGAGT & Primer GCAAGCACCCTATCAGGCAGT \\
\hline
\end{tabular}

${ }^{a}$ Numbering according to Wang et al. (1993), where the ATG start codon for the polyprotein precursor gene is located at nucleotide position 342 [6] Primer-probe sequences are presented in the $5^{\prime}$ to $3^{\prime}$ orientation

The assay was designed as a qualitative singleplex RTPCR assay with parallel detection of HCV and PDV in separate wells. Both the HCV and PDV reactions were optimised to a final reaction volume of $50 \mu \mathrm{l}$, containing $10 \mu \mathrm{l}$ of cDNA and $40 \mu \mathrm{l}$ of PCR mixture. This PCR mixture contained $25 \mu \mathrm{l}$ of TaqMan ${ }^{\circledR} 2 \times$ Universal PCR Master Mix (Applied Biosystems), $0.3 \mu \mathrm{M}$ of HCV-specific primers and $0.25 \mu \mathrm{M}$ of $\mathrm{HCV}$-specific MGB probe, or $0.3 \mu \mathrm{M}$ of PDV-specific primers and $0.25 \mu \mathrm{M}$ of PDVspecific MGB probe. Primer and probe concentrations were optimised for both reactions using "matrix guidelines" from Applied Biosystems. The amplification protocol for both gene targets included an initial denaturation step at $95^{\circ} \mathrm{C}$ for $10 \mathrm{~min}$, followed by 50 cycles at $95^{\circ} \mathrm{C}$ for $15 \mathrm{~s}$ and $60^{\circ} \mathrm{C}$ for $1 \mathrm{~min}$.
Following the optimisation of a singleplex assay, efforts were made to develop the assay into a qualitative multiplex format. The PDV amplification reaction was optimised as a primer-limited assay using the "limiting primer matrix" (Applied Biosystems 2001). For the multiplex assay, $10 \mu \mathrm{l}$ of cDNA was added to $40 \mu \mathrm{l}$ of reaction mixture containing $25 \mu$ of TaqMan ${ }^{\circledR}$ Universal PCR Master Mix, $0.3 \mu \mathrm{M}$ of $\mathrm{HCV}$-specific primers, $0.1 \mu \mathrm{M}$ of PDV-specific primers and $0.25 \mu \mathrm{M}$ of both HCV-specific and PDV-specific MGB probes.

The LOD for the HCV assay was determined using a dilution series of the WHO Standard, covering a range from $10 \mathrm{IU} / \mathrm{ml}$ to $10,000 \mathrm{IU} / \mathrm{ml}$. The sensitivity of the assay was also monitored by testing the external QCMD 2002 and 2004 HCV Proficiency Panels. Genotype specificity of the

Table 2 Multiple sequence alignment for phocine distemper virus (PDV)-specific primer-probe set for the haemagglutinin gene of PDV

\begin{tabular}{llllll}
\hline $\begin{array}{l}\text { PDV forward primer (nucleotide position } \\
\text { 41-62 }\end{array}$ & $\begin{array}{l}\text { PDV probe (nucleotide position } \\
64-78^{\mathrm{a}} \text { ) }\end{array}$ & PDV reverse primer (nucleotide position 101-123 \\
\hline DK881a(H)GGTGGGTGCCTTTTACAAGAAC & DK881a(H)ATGCAAGGGCCAATT & DK881a(H)GGACGAGGTTGAGGAAAGAAGAT \\
DK884a(H)GGTGGGTGCCTTTTACAAGAAC & DK884a(H)ATGCAAGGGCCAATT & DK884a(H)GGACGAGGTTGAGGAAAGAAGAT \\
$4 \mathrm{a}(\mathrm{H})$ & GGTGGGTGCCTTTTACAAGAAC & $4 \mathrm{a}(\mathrm{H})$ & ATGCAAGGGCCAATT & $4 \mathrm{a}(\mathrm{H})$ & GGACGAGGTTGAGGAAAGAAGAT \\
$(\mathrm{H})$ & GGTGGGTGCCTTTTACAAGAAC & $(\mathrm{H})$ & ATGCAAGGGCCAATT & $(\mathrm{H})$ & GGACGAGGTTGAGGAAAGAAGAT \\
& $* * * * * * * * * * * * * * * * * * * *$ & & $* * * * * * * * * * * * * *$ & & $* * * * * * * * * * * * * * * * * * * *$ \\
Primer & GGTGGGTGCCTTTTACAAGAAC & Probe & ATGCAAGGGCCAATT & Primer & ATCTTCTTCCTCAACCTCGTCC
\end{tabular}

${ }^{\text {a }}$ Numbering according to Nielsen (2002), where the ATG start codon for the haemagglutinin gene is located at nucleotide position 21 [7]

Primer-probe sequences are presented in the $5^{\prime}$ to $3^{\prime}$ orientation 
assay was monitored by testing the HCV RNA Genotype Panel for Nucleic Acid Amplification Techniques (NIBSC code $02 / 202$ ). To determine reproducibility, clinical samples $(n=32)$, the WHO dilution series and the QCMD panels were tested in three separate assay runs using the same batches of reagents.

The singleplex assay was evaluated by comparing the results obtained for 200 serum samples (99 HCV-positive, nine HCV-low-positive and $92 \mathrm{HCV}$-negative) with results obtained from the COBAS AMPLICOR assay. An HCVlow-positive sample was defined as a sample which yielded an equivocal HCV result (absorbance at $660 \mathrm{~nm} \geq 0.15<1.0$ ) on initial testing and subsequently demonstrated absorbance values $\geq 0.15$ on repeat testing in duplicate. The results of the nine HCV-low-positive samples were also compared with the results obtained by the VERSANT ${ }^{\circledR}$ HCV RNA assay v3.0 (Bayer Diagnostics, Berkeley, CA). The multiplex assay was evaluated by testing representative samples from the clinical trial group $(n=28)$. A sample was considered as a true positive/negative if an HCV-positive/negative result, respectively, was obtained by the COBAS AMPLICOR assay.

\section{Results}

HCV cycle threshold $(\mathrm{Ct})$ values for the ABI $6100 \mathrm{RNA}$ extracts (mean=36.0) were within one $\mathrm{Ct}$ value of those obtained from UltraSens ${ }^{\mathrm{TM}}$ extracts $(\mathrm{mean}=35.2)$, with a $95 \%$ confidence interval $(\mathrm{CI})$ of 0.6 to $0.9(P<0.001)$. In the singleplex assay, $\mathrm{Ct}$ values for $\mathrm{HCV}$ - and $\mathrm{PDV}$-positive signals ranged from $22.5-42.5$ and 35.7-39.3, respectively. Using a dilution series of the WHO Standard for HCV, the LOD was determined as $100 \mathrm{IU} / \mathrm{ml}$ (Table 3). In accordance with the qualitative QCMD rating, the assay achieved a maximum performance score for QCMD HCV Proficiency Panels 2002 and 2004 (Table 4). All HCV genotypes in the HCV RNA Genotype Panel for Nucleic Acid Amplification

Table 3 Observed cycle threshold $(\mathrm{Ct})$ values for dilution series of HCV RNA WHO Standard (Panel A) and HCV genotype panel (NIBSC) (Panel B)

\begin{tabular}{|c|c|c|c|}
\hline \multicolumn{2}{|l|}{ Panel A } & \multicolumn{2}{|l|}{ Panel B } \\
\hline Standard (IU/ml) & Observed $\mathrm{Ct}$ & $\begin{array}{l}\text { Genotype } \\
1,000 \mathrm{IU} / \mathrm{mL}\end{array}$ & Observed $\mathrm{Ct}$ \\
\hline 10,000 & 31.2 & 1 & 37.0 \\
\hline 5,000 & 32.4 & 2 & 35.2 \\
\hline 1,000 & 34.6 & 3 & 36.8 \\
\hline 500 & 35.2 & 4 & 36.4 \\
\hline 250 & 36.2 & 5 & 36.5 \\
\hline 100 & 37.2 & 6 & 38.4 \\
\hline 50 & Undetected & & \\
\hline
\end{tabular}

Techniques were detected (Table 3). The singleplex assay also displayed good reproducibility with the results for clinical samples $(n=32)$, the WHO dilution series and the QCMD panels, falling within $1.5 \mathrm{Ct}$ values of each other.

In the singleplex assay, 107 of the $108 \mathrm{HCV}$-positive samples tested yielded a positive result, thereby, demonstrating a sensitivity of $99.0 \%$. The resulting negative predictive value was $98.9 \%$. The positive sample that remained undetected in the clinical trial had previously failed to be detected by the VERSANT ${ }^{\circledR}$ assay (LOD $<3,200$ copies $/ \mathrm{ml}$ ), but yielded a positive result by the COBAS assay $(\mathrm{LOD}=50 \mathrm{IU} / \mathrm{ml})$, albeit within the low-positive category, as defined above. All $92 \mathrm{HCV}$-negative samples in the clinical trial yielded a negative result. The specificity and positive predictive value for the singleplex assay were, therefore, $100 \%$.

In the multiplex assay, $\mathrm{Ct}$ values for $\mathrm{HCV}$-positive signals demonstrated a wider range than the singleplex assay (22.0-48.5). HCV amplification plots demonstrated a mean increase of 1.5 in $\mathrm{Ct}$ values $(95 \% \mathrm{CI}$ of $0.4-2.5, P=$ $0.01)$ compared to the singleplex assay. For PDV-positive signals, the range of $\mathrm{Ct}$ values also widened (35.9-48.0), with a mean increase of 3.6 in individual $\mathrm{Ct}$ values $(95 \% \mathrm{CI}$ of 2.5-4.8, $P<0.001$ ) (Table 5). Nevertheless, using the multiplex format, the PDV internal control was detected in all samples. The LOD of the multiplex assay was the same as that observed for the singleplex assay $(100 \mathrm{IU} / \mathrm{ml})$. Of the $28 \mathrm{HCV}$ samples tested in multiplex, 27 yielded the correct $\mathrm{HCV}$ result, with only one false-negative occurring. This sample also yielded a false-negative result in the singleplex assay.

\section{Discussion}

The direct detection of HCV RNA has become an essential tool for the diagnosis of hepatitis $\mathrm{C}$ infection. The qualitative RT-PCR assay developed demonstrated high sensitivity (99.0\%) and an acceptable LOD of $100 \mathrm{IU} / \mathrm{ml}$, which is comparable to other in-house HCV PCR detection assays $[8,9]$. This LOD falls within the recommended detection limits for HCV RNA assays (100 IU/ml) [10], although many commercial assays have a claimed an LOD of $50 \mathrm{IU} / \mathrm{ml}$. Only one of $108 \mathrm{HCV}$-positive samples tested in the clinical trial was missed. This sample was undetected in the VERSANT assay, which has an LOD value of $<3,200$ copies $/ \mathrm{ml}$. However, since the sample demonstrated a lowpositive result by the COBAS AMPLICOR system, which has an LOD of $50 \mathrm{IU} / \mathrm{ml}$, it is likely to represent a true positive with a low viral load.

The assay also displayed excellent specificity, with the detection of all genotypes in the NIBSC HCV RNA Genotype Panel and the QCMD HCV Proficiency Panels 
Table 4 Observed cycle threshold $(\mathrm{Ct})$ values for QCMD HCV proficiency panels

\begin{tabular}{llllll}
\hline QCMD 2002 & Target concentration range $(\mathrm{IU} / \mathrm{mL})$ & Observed Ct & QCMD 2004 & Target concentration (IU/mL) & Observed Ct \\
\hline HCV 1 & $2-20 \times 10^{4}(+)^{\mathrm{a}}$ & $30.5(+)$ & HCV 17 & $8.3 \times 10^{3}(+)$ & $32.2(+)$ \\
HCV 2 & $1-4 \times 10^{5}(+)$ & $27.2(+)$ & HCV 18 & $1.7 \times 10^{3}(+)$ & $33.3(+)$ \\
HCV 3 & BLD $^{\mathrm{b}}-1,200(+)$ & $39.5(+)$ & HCV 19 & $1.7 \times 10^{2}(+)$ & $39.0(+)$ \\
HCV 4 & $1-5 \times 10^{4}(+)$ & $30.9(+)$ & HCV 20 & $8.3 \times 10^{4}(+)$ & $28.5(+)$ \\
HCV 5 & $1-8 \times 10^{3}(+)$ & $37.2(+)$ & HCV 21 & $8.3 \times 10^{3}(+)$ & $31.5(+)$ \\
HCV 6 & $1-8 \times 0^{3}(+)$ & $36.4(+)$ & HCV 22 & $3.4 \times 10^{3}(+)$ & $33.2(+)$ \\
HCV 7 & BLD $-1,200(+)$ & Undetected $(-)$ & HCV 23 & $8.3 \times 10^{4}(+)$ & $26.8(+)$ \\
HCV 8 & Neg $(-)^{\mathrm{c}}$ & Undetected $(-)$ & HCV 24 & Negative $(-)$ & Undetected $(-)$ \\
\hline
\end{tabular}

${ }^{\text {a }}(+)=$ positive signal

$\mathrm{b}$ BLD=below limit of detection

c $(-),=$ negative signal

Table 5 Comparison of cycle threshold $(\mathrm{Ct})$ values observed for $\mathrm{HCV}$ and PDV target in the singleplex and multiplex assays

\begin{tabular}{|c|c|c|c|c|}
\hline Sample no. & $\begin{array}{l}\text { Singleplex } \\
\mathrm{HCV} C t\end{array}$ & $\begin{array}{l}\text { Multiplex } \\
\text { HCV Ct }\end{array}$ & $\begin{array}{l}\text { Singleplex } \\
\text { PDV Ct }\end{array}$ & $\begin{array}{l}\text { Multiplex } \\
\text { PDV Ct }\end{array}$ \\
\hline 1 & 34.0 & 34.1 & 37.7 & 42.2 \\
\hline 2 & 34.0 & 33.4 & 37.1 & 47.4 \\
\hline 3 & 37.3 & 39.6 & 37.4 & 47.0 \\
\hline 4 & 37.9 & 42.3 & 37.3 & 45.9 \\
\hline 5 & 40.1 & 45.9 & 37.2 & 43.3 \\
\hline 6 & 40.9 & 48.5 & 38.2 & 47.4 \\
\hline 7 & 40.7 & 45.5 & 37.9 & 38.6 \\
\hline 8 & 25.3 & 24.7 & 36.8 & 38.4 \\
\hline 9 & 22.5 & 22.1 & 36.0 & 37.4 \\
\hline 10 & 22.8 & 22.0 & 35.9 & 36.5 \\
\hline 11 & 24.7 & 23.8 & 38.7 & 39.9 \\
\hline 12 & 25.5 & 24.7 & 36.9 & 37.5 \\
\hline 13 & 22.5 & 23.5 & 37.1 & 37.8 \\
\hline 14 & 22.8 & 23.5 & 37.6 & 37.7 \\
\hline 15 & 23.1 & 23.8 & 36.1 & 35.9 \\
\hline 16 & 24.4 & 25.2 & 36.3 & 36.8 \\
\hline 17 & 22.9 & 23.9 & 37.4 & 44.1 \\
\hline 18 & 42.5 & 38. & 39.3 & 43.3 \\
\hline 19 & 38.8 & 39.1 & 35.9 & 48.4 \\
\hline 20 & 36.7 & 38.3 & 37.1 & 48.0 \\
\hline 21 & 40.8 & 47.1 & 37.2 & 43.6 \\
\hline 22 & 36.1 & 37.2 & 36.8 & 38.9 \\
\hline 23 & 36.6 & 39.5 & 35.7 & 37.9 \\
\hline 24 & 35.1 & 35.5 & 36.1 & 40.1 \\
\hline 25 & 37.3 & 40.0 & 36.4 & 38.1 \\
\hline 26 & Undetected & Undetected & 35.8 & 37.7 \\
\hline 27 & Undetected & Undetected & 37.6 & 39.9 \\
\hline 28 & Undetected & Undetected & 37.3 & 39.4 \\
\hline Mean & 31.7 & 33.1 & 37.0 & 40.7 \\
\hline $\begin{array}{l}\text { Standard } \\
\text { deviation }\end{array}$ & 7.8 & 9.5 & 0.9 & 3.8 \\
\hline $\begin{array}{l}95 \% \text { lower- } \\
95 \% \text { upper }\end{array}$ & $0.4-2.5$ & & $2.5-4.8$ & \\
\hline
\end{tabular}

2002 and 2004. Using the singleplex assay, full marks were obtained for both panels. In addition to high sensitivity and specificity, the hybridisation probe assay yielded highly reproducible results, with results not varying by more than $1.5 \mathrm{Ct}$ values on repeat testing.

Although the HCV results of samples tested in multiplex remained unchanged from the singleplex assay, the $\mathrm{Ct}$ values of HCV and PDV target increased in the multiplex format. The reason for this $\mathrm{Ct}$ increase is currently unknown, but may be due to primer limitation or primer-dimer formation. Nevertheless, the multiplex assay yielded sensitivity (95.8\%), specificity $(100 \%)$ and LOD $(100 \mathrm{IU} / \mathrm{ml})$ rates similar to the singleplex assay. Preliminary results of the multiplex clinical trial are promising and indicate that this assay may be used for the qualitative detection of $\mathrm{HCV}$.

It is increasingly recognised that the use of a universal internal control helps to enhance the performance of molecular virology techniques $[11,12]$. This study, therefore, incorporated the design of a second RT-PCR assay for the detection of a viral RNA internal control. PDV was added directly to the samples in low concentration as a viral substrate. As PDV behaves in a more similar manner to the $\mathrm{HCV}$ target, it can simulate the extraction, amplification and detection of HCV. This methodology confirmed that there was no significant loss of sample during the extraction procedure and that there were no inhibitors to reverse transcription or amplification in the samples. International collaboration among diagnostic laboratories to implement PDV as a universal RNA viral internal control could represent a step towards the standardisation of molecular virology assays [11].

Aside from the design of an accurate $\mathrm{HCV}$ detection assay, this study also addressed other important design facets of molecular diagnostic assays. Many nucleic acid extraction systems are designed for dedicated commercial assays, but offer little flexibility for in-house assay design. This study incorporated the development of a high-yield, high-purity HCV RNA extraction method using the semiautomated ABI PRISM ${ }^{\text {TM }} 6100$ Nucleic Acid PrepStation 
(Applied Biosystems, Foster City, CA). This system enabled rapid high-throughput purification, thus, helping to overcome the cost issues associated with automation and the time factors associated with manual extraction procedures. The lack of PCR inhibitors observed in this study reflects the high purity of viral RNA isolated using the optimised semiautomated ABI 6100 extraction protocol. Furthermore, the results for the ABI 6100 extracts compared well to the results for extracts from the manual UltraSens ${ }^{\mathrm{TM}}$ Kit.

The HCV assay developed in this study represents a robust and reliable RT-PCR method for the detection of hepatitis $\mathrm{C}$ in serum samples. The assay design incorporated the use of semi-automated extraction, a viral substrate internal control, a two-step RT-PCR procedure and a flexible singleplex or multiplex format and represents an attractive alternative to commercial HCV PCR systems.

Acknowledgements Thanks go to Mr. Martin Lawrence from the Department of Clinical Microbiology, St. James's Hospital, Dublin 8, Ireland, for his help with the statistics in this paper.

\section{References}

1. Shepard CW, Finelli L, Alter MJ (2005) Global epidemiology of hepatitis C virus infection. Lancet Infect Dis 5:558-567, DOI 10.1016/S1473-3099(05)70216-4

2. Krajden M (2000) Hepatitis C virus diagnosis and testing. Can J Public Health 91(Suppl 1):S34-S42
3. Erensoy S (2001) Diagnosis of hepatitis C virus (HCV) infection and laboratory monitoring of its therapy. J Clin Virol 21:271-281, DOI 10.1016/S1386-6532(00)00170-0

4. Germer JJ, Zein NN (2001) Advances in the molecular diagnosis of hepatitis C and their clinical implications. Mayo Clin Proc 76 (9):911-920

5. Niesters HGM (2002) Clinical virology in real time. J Clin Virol 25:S3-S12, DOI 10.1016/S1386-6532(02)00197-X

6. Wang Y, Okamoto H, Tsuda F, Nagayama R, Tao QM, Mishiro S (1993) Prevalence, genotypes, and an isolate (HC-C2) of hepatitis $\mathrm{C}$ virus in Chinese patients with liver disease. J Med Virol 40 (3):254-260, DOI 10.1002/jmv.1890400316

7. Nielsen L (2002) Direct submission. Submitted 1st February 2002. Royal Veterinary and Agricultural University, Laboratory of Virology and Immunology, Bulowsvej 17, Frederiksberg, C 1870, Denmark

8. Hourfar MK, Schmidt M, Seifried E, Roth WK (2005) Evaluation of an automated high-volume extraction method for viral nucleic acids in comparison to a manual procedure with preceding enrichment. Vox Sang 89:71-76, DOI 10.1111/j.1423-0410.2005.00649.x

9. Forcić D, Zgorelec R, Branović K, Kosutić-Gulija T, Santak M, Mazuran R (2001) Incidence of hepatitis C virus RNA in antiHCV negative plasma pools in Croatia. Transfus Apher Sci 24 (3):269-278, DOI 10.1016/S1473-0502(01)00069-6

10. Flanagan P, Snape T (1998) Nucleic acid technology (NAT) testing and the transfusion service: a rationale for the implementation of minipool testing. Transfus Med 8:9-13, DOI 10.1046/ j.1365-3148.1998.00130.x

11. Niesters HGM (2004) Molecular and diagnostic clinical virology in real time. Clin Microbiol Infect 10:5-11, DOI 10.1111/j.14690691.2004.00699.x

12. Castelain S, Descamps V, Thibault V, François C, Bonte D, Morel V, Izopet J, Capron D, Zawadzki P, Duverlie G (2004) TaqMan amplification system with an internal positive control for $\mathrm{HCV}$ RNA quantitation. J Clin Virol 31:227-234 